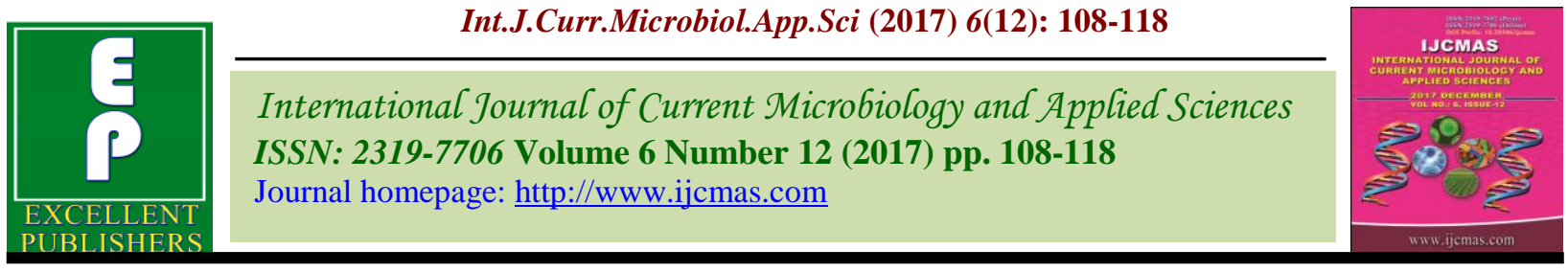

Original Research Article

https://doi.org/10.20546/ijcmas.2017.612.015

\title{
Design of Computer Aided Drip Irrigation System Software
}

\author{
N.V. Gowtham Deekshithulu*, G. Ravi Babu, H.V. Hema Kumar and R. Ganesh Babu \\ College of Agricultural Engineering, Bapatla, Andhra Pradesh, India \\ *Corresponding author
}

A B S T R A C T

\begin{tabular}{|l|}
\hline Ke y w or d s \\
$\begin{array}{l}\text { Drip irrigation, } \\
\text { System software, } \\
\text { Visual basic. }\end{array}$ \\
\hline Article Info \\
\hline $\begin{array}{l}\text { Accepted: } \\
\text { 04 October } 2017 \\
\text { Available Online: } \\
\text { 10 December } 2017\end{array}$ \\
\hline
\end{tabular}

Drip or trickle irrigation is one of the latest methods of irrigation which is becoming increasingly popular in areas with water scarcity and salt problems. The Government of India recognized the importance of micro irrigation and announced subsidy schemes in few selected states in 1991. Different crops require different plant spacings and irrigation requirements. The general layout of the system and the location of the emitters will depend on the type of crop. This paper describes a windows based computer application developed for designing efficient drip irrigation facilities using Visual Basic 6. The concern for an arrangement of this type is justified by the superior advantages offered by drip irrigation compared to other methods. This software is user-friendly and provides interaction at all stages of the design process and a solution based on individual's requirements and the information base available within the software. The individual not only can suit to his requirement but can also compare his design with several other alternate designs with different inputs. Design of system arrived by this software was tested with manual calculations at developer's level and results were found satisfactory.

\section{Introduction}

Drip irrigation system requires pressurized pipe network with lower operating pressure and lower rate of water application. In this case, the water is applied at a low rate varying from 2-10 lph to keep the soil moisture within the desired range for plant growth (Modi, 2004). The drip irrigation pipe network consists of lateral, submain and main lines. The laterals are designed to distribute irrigation water throughout the field with an acceptable degree of uniformity. The submain delivers water to the laterals and also needs adequate designing to achieve uniform flow to the lateral lines. The main line serves as a conveyance system for delivering the total amount of water at the required water pressure for the entire irrigation system. The development of new LLDPE plastic for trickle irrigation lateral lines and other plastic materials for emitters has resulted in increased research and development on drip irrigation, followed by its adoption.

In India, 91.6 percent of the water is used for irrigation purpose as compared to 64 percent in Asia and 71 percent in the world (Irrigation in Asia in figures, Water Reports No. 18, FAO, 1999). The expected climate change in $21^{\text {st }}$ century will have pronounced negative impact on overall water availability and its quality. Water resources of the country are depleting at an alarming rate and further, 
growing population coupled with changing lifestyles are putting more pressure on sharing the available resources.

Under these circumstances, it is needed to popularize drip irrigation method in various states of the country through extension services by disseminating the information about technology needed and economic benefits of drip irrigation and help to reduce over exploitation of water resources of the country. Scientific water management, farm practices, sprinkler and drip system of irrigation should be adopted wherever feasible. The result indicated that the water required by crop in drip irrigation system was only $1 / 3^{\text {rd }}$ to $1 / 4^{\text {th }}$ of that required by surface irrigation method and the crop yield was found to be higher in drip system. Till date, about 2.5 lakh hectare area is under drip irrigation in India and Maharashtra is the leading state amongst all.

A major difference between drip irrigation system and most other conventional systems is that the balance between crop evapotranspiration and applied water is maintained over limited periods at 24 to 72 hours. The limited capacity of drip irrigation system operating over this short time interval requires that particular attention be applied for estimation of crop water requirement or measurement of soil water status in the root zone (Michael and Ojha, 2006). The capacity of the system is determined to meet the irrigation requirement of the area for the crops to be irrigated, their spacing, soil moisture characteristics and climatic conditions influencing evapotranspiration rates.

As it is difficult to calculate water requirements of the crops, discharge requirement of the pump set, pressure losses in the various pipes, discharge variation along the laterals etc., manually. Commercially for various distributors, they need to design and install many systems within a district of their jurisdiction. If the field staff or technical staff is sufficiently trained, this simple software will act like a boon in maintaining their time schedule. Progressive farmers can also easily operate and design their system by themselves. By ordering the spares, they can themselves install the system as per their requirements. Keeping the above considerations, it is to be made an attempt by developing an computer based application which was entitled as "Design of computer aided drip irrigation system software using visual basic 6.0 ".

\section{Materials and Methods}

\section{Basic information required}

The designed software for drip irrigation system was developed using Microsoft Visual Basic 6.0. The software was developed to design of drip irrigation system, with taking onto calculation of crop water requirement, friction head loss of main line and operating pressure of system, which are very important for drip irrigation system design. It includes different formulae and theoretical consideration those are used while developing the software. Before you can program in VB 6 , you need to install Visual Basic 6 in your computer.

Hydraulic principles govern the flow of water through irrigation pipes. A basic understanding of these principles is necessary for understanding the design and operation of irrigation systems (Boman and Shukla, 2004).

\section{Estimation of crop water requirement}

Water requirement can be calculated by following formula:

Peakwaterrequirement $=\frac{A x B X C x D}{E}$ 
Where;

$\mathrm{A}=$ Potential evapotranspiration rate (mm/day)

$\mathrm{B}=$ Crop factor depends on growth stage and foliage

$\mathrm{C}=$ Canopy Factor i.e. $\frac{\text { Area of plant shadow at } 12 \text { noon }}{\text { Plant spacing } x \text { Row spacing }}(2)$

$\mathrm{D}=$ Area provided to plant (sq. meter)

$\mathrm{E}=$ Efficiency of system (drip irrigation$90 \%$ )

$\mathrm{ET}_{\mathrm{O}}=$ Reference evapotranspiration or potential evapotranspiration ( $\mathrm{mm}$ )

$E T_{\circ}=E_{p} x K_{p}(3)$

$E_{P}=$ Evaporation from USWB open pan evaporiameter

$K_{P}=$ Pan co-efficient

$\mathrm{ET}_{\mathrm{C}}=$ Evapotranspiration of crop i.e., $E T_{C}=E T_{\circ} x K_{C}(4)$

$\mathrm{K}_{\mathrm{C}}=$ Crop co-efficient (The average crop coefficient values are given in table 1)

\section{Friction loss equation}

It is important to determine the amount of energy or friction head lost in pipes in order to properly size them. Friction loss in pipes depends on flow (Q), pipe diameter (D) and pipe roughness $(\mathrm{C})$. The smoother the pipe, the higher the $\mathrm{C}$ value. The $\mathrm{C}$ values for different materials are given in table 2 . Increasing flow rate or choosing a rougher pipe will increase energy losses, resulting in decreased pressures downstream. The Hazen - Williams equation is extensively used for designing water distribution systems. The Darcy - Weisbach equation is the most accurate in predicting friction loss in pipe lines. But it is cumbersome to use (SankaraReddi and YellamandaReddi, 1995). Hazen and Williams formula is the most widely used.

The total energy drop for lateral or submain can be determined by introducing an $\mathrm{F}$ value, as a reduction coefficient, this is called as outlet factor $F$. The head loss formula is expressed according to (Mane, et al., 2014)

$\Delta H=K\left(\frac{Q}{c}\right)^{1.852} x D^{-4.871} x \operatorname{LxF}(5)$

$\Delta \mathrm{H}=$ The head loss in pipe, $\mathrm{m}$

$\mathrm{K}=$ Constant, $1.21 \times 10^{10}$

$\mathrm{Q}=$ The flow rate in the pipe, $1 / \mathrm{sec}$

$\mathrm{C}=$ The friction coefficient for continuous section of the pipe and depends on the pipe material.

$\mathrm{D}=$ The inside diameter, $\mathrm{mm}$

$\mathrm{L}=$ The length of pipe, $\mathrm{m}$

$\mathrm{F}=$ The outlet factor

$F=\frac{1}{m+1}+\frac{1}{2 n}+\frac{(m+1)^{0.5}}{6 n^{2}}(6)$

\section{Steps in design of drip irrigation system}

In general following are the basic steps involved in design (Mane, et al., 2014)

Type of crop

Selection of dripper (emitter)

Selection and design of lateral

Selection and design of submain

Selection and design of main line Selection of pump 


\section{Type of crop}

General layout of the system and specially lateral and emitter spacing will depend upon the type of crops to be grown in that area, as different crops have different plant spacing and irrigation requirement.

\section{Selection of drippers}

The selection of dripper type and number of drippers per plant is depends on peak water requirement of the crop and the infiltration rate of soil. The emitter must supply enough water to the plant root zone to meet the crop water requirement. Spacing of the dripper is according to the intra row spacing of the plants. Water application rate is adjusted by using drippers which discharge at the desired application rates. Normally, $1 / 3^{\text {rd }}$ to as much as $3 / 4^{\text {th }}$ of the plant rooting volume should be supplied with adequate water. Emitter can be on single lateral with equal spacing, double laterals, and laterals with loops or other configurations. Drip irrigation emitter can be designed as a point source or line source to supply water into the plant root zone depending on the type of crops. The required emitter flow can be calculated based on the water requirement of the crop, no. of emitters per plant, irrigation application efficiency of drip irrigation system and the duration of irrigation.

\section{Selection and design of lateral}

Lateral carries water from submain and feeds to the individual drippers. The size and length of lateral is decided by the discharge of the drippers and no. of dripper on one lateral. The laterals are small diameter flexible pipes or tubes made up of low density polyethylene (LDPE) or linear low density polyethylene (LLDPE) of $12 \mathrm{~mm}, 16 \mathrm{~mm}$ and $20 \mathrm{~mm}$ diameter. There colour is black to avoid the algae growth and the effect of ultraviolet radiation. They can withstand the maximum pressure of 2.5 to $4.5 \mathrm{~kg} / \mathrm{cm}^{2}$. They are connected to the submain by using grommet and take off as per row spacing of the crop.

\section{Selection and design of submain}

Submain is generally made up of PVC (poly vinyl chloride) pipes of $32 \mathrm{~mm}, 40 \mathrm{~mm}, 50$ $\mathrm{mm}, 63 \mathrm{~mm}$ and $75 \mathrm{~mm}$ in diameter.

The design of submain is based on both capacity and uniformity. Capacity means the submain size should be large enough to deliver the required amount of water to irrigate the subsequent part of the field. Uniformity means the submain should be design to maintain an allowable pressure variation, so that flow into all lateral lines taking from it will have little variation. The size and length of submain is determined by number of laterals and distance between the laterals.

\section{Selection and design of mainline}

The main line design is based on topography, the operating pressure, the field layout of laterals and submains and the required discharge from each outlet along the main line.

The main line system has changing flow capacity with respect to length. The main line design is to select the proper pipe diameter for each section to deliver water at the required rate to all submains and distribution lines in the system. There are a number of pipe sizes to meet the hydraulic requirement of a given layout.

Generally the size of mainline is one size higher than submain. The size of the main line is decided by flow rate of the entire submain. The sizes of mainline are $40 \mathrm{~mm}, 50 \mathrm{~mm}, 63$ $\mathrm{mm}, 75 \mathrm{~mm}, 90 \mathrm{~mm}$ and $110 \mathrm{~mm}$ etc. 


\section{Selection of pump}

The duty of the pump in terms of flow and pressure is determined after the diameter, length and discharge of all the mains, laterals and emitters are decided and the friction losses are estimated.

Total Head of Pump $=$ suction head + delivery head + filter losses + mainline loss operating pressure + fitting loss + venturi head loss + elevation difference (7)

Where;

Filter losses are assumed to be $2 \mathrm{~m}$ for screen filter (disc filter) and $2 \mathrm{~m}$ for sand filter.

Operating pressure is about $1 \mathrm{~kg} / \mathrm{cm}^{2}(10 \mathrm{~m}$.)

Fitting loss $=2 \mathrm{~m}$

Venturi head loss $=5 \mathrm{~m}$.

Required HP for the pump is calculated as-

$H . P=\frac{Q x H}{75 x a x b}(8)$

Where;

$\mathrm{Q}=$ The maximum flow rate of system, $1 / \mathrm{sec}$

$\mathrm{H}=$ The total head of the system, $\mathrm{m}$

$\mathrm{a}=$ The motor efficiency, generally taken as $80 \%$

$\mathrm{b}=$ The pump efficiency, generally taken as $75 \%$

H.P $=$ The Horse Power.

\section{Results and Discussion}

Software includes following steps for design of drip irrigation system

Calculation of water requirement
Selection of dripper

Selection and design of lateral

Selection and design of submain

Selection and design of mainline

Selection of pump

Details of dimensions

For these steps the seven different forms are designed as shown in Fig. 1 to 7.

\section{Calculation of crop water requirement}

1. Select the desired crop from the available crops in combo box.

2. Enter the values of plant to plant and row to row distance in meter.

3. Enter area of plant shadow at 12 noon and E-pan values in the input box.

4. Click on submit button to get crop water requirement in $1 /$ day/plant.

5. Click on Next button to get next form.

\section{Selection of dripper}

1. Select the Dripper from the available list of dripper sizes viz., 2 lph, 4 lph, 8 lph, 16 lph.

2. Enter the number of drippers per plant which are required and length and width of the field.

3. Click on Submit button to get irrigation time in hour.

4. Click on Next button to get next form.

5. To go to previous form click on Back button.

\section{Selection and design of lateral}

1. Select the lateral diameter from the available list viz., $12 \mathrm{~mm}, 16 \mathrm{~mm}$, and $20 \mathrm{~mm}$.

2. Enter the length lateral to be required in meter.

3. Select the pipe material that is used for design of the system and the friction factor will show the value according to the material selected. 
4. Click on Submit button, if lateral fraction head loss is less than 2 meter then message box will show "Your selected lateral size is good, the calculated head loss is sufficient to carry the flow, go to next" Otherwise message box will display your selected lateral size is wrong, the calculated head loss is not sufficient to carry the flow, change the diameter".

5. Text box below shows the selected internal Diameter of the lateral.

6. Click on Next button to get next form.

7. To go to previous form, click on Back button.

Fig.1 Crop water requirement form

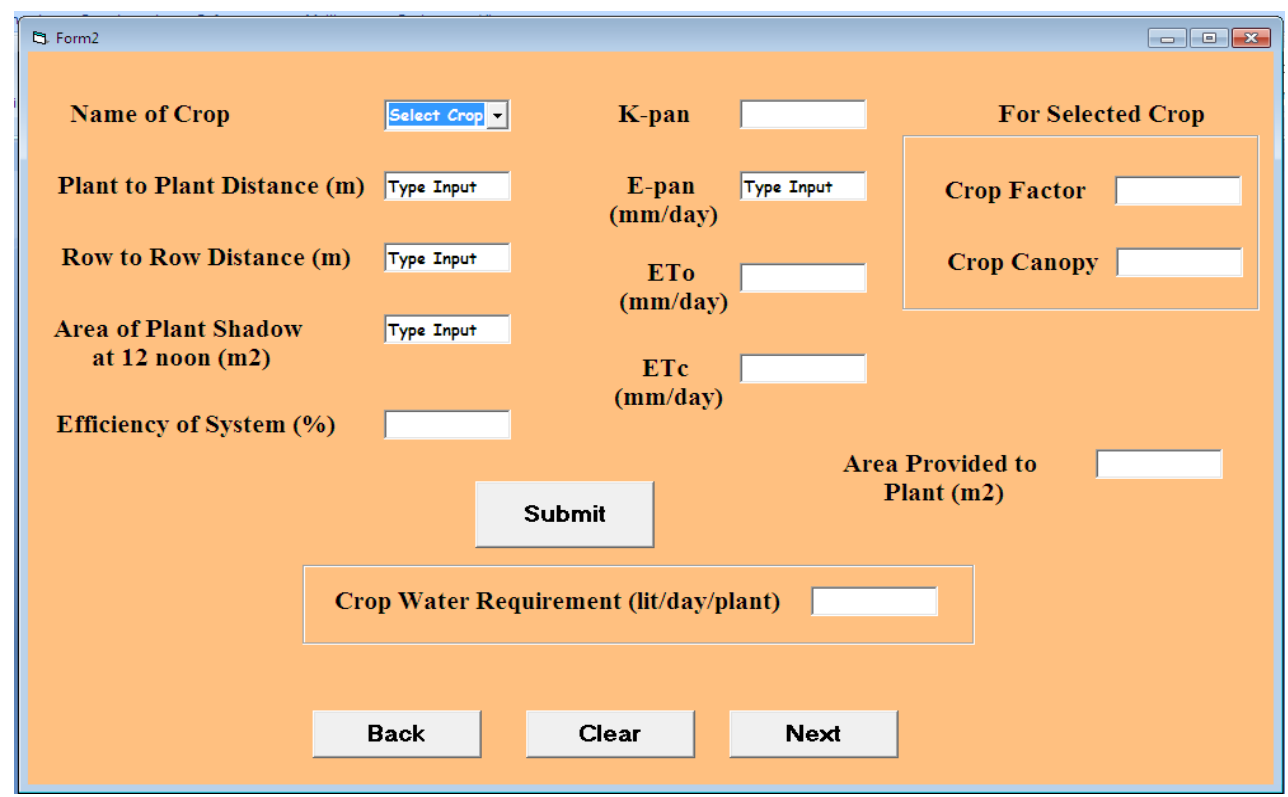

Fig.2 Selection of dripper form

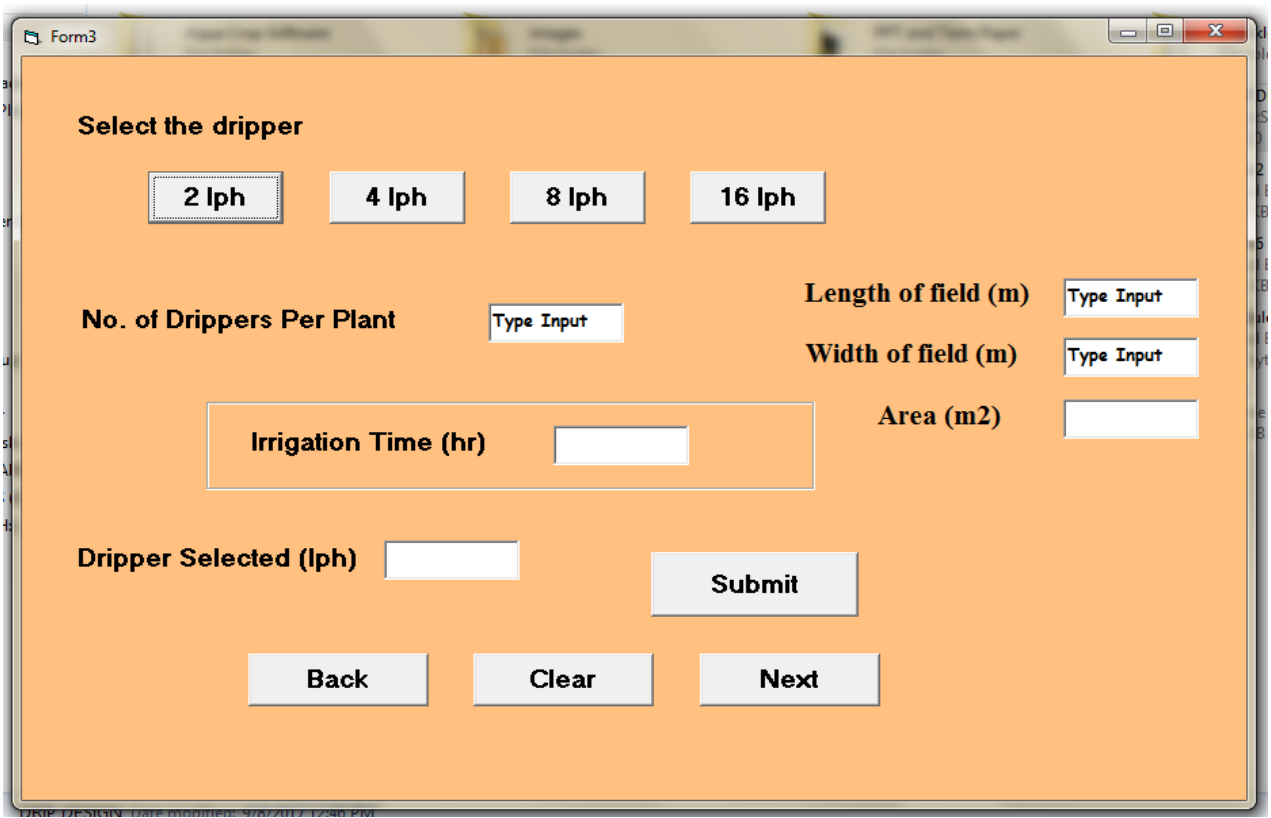


Fig.3 Design of lateral form

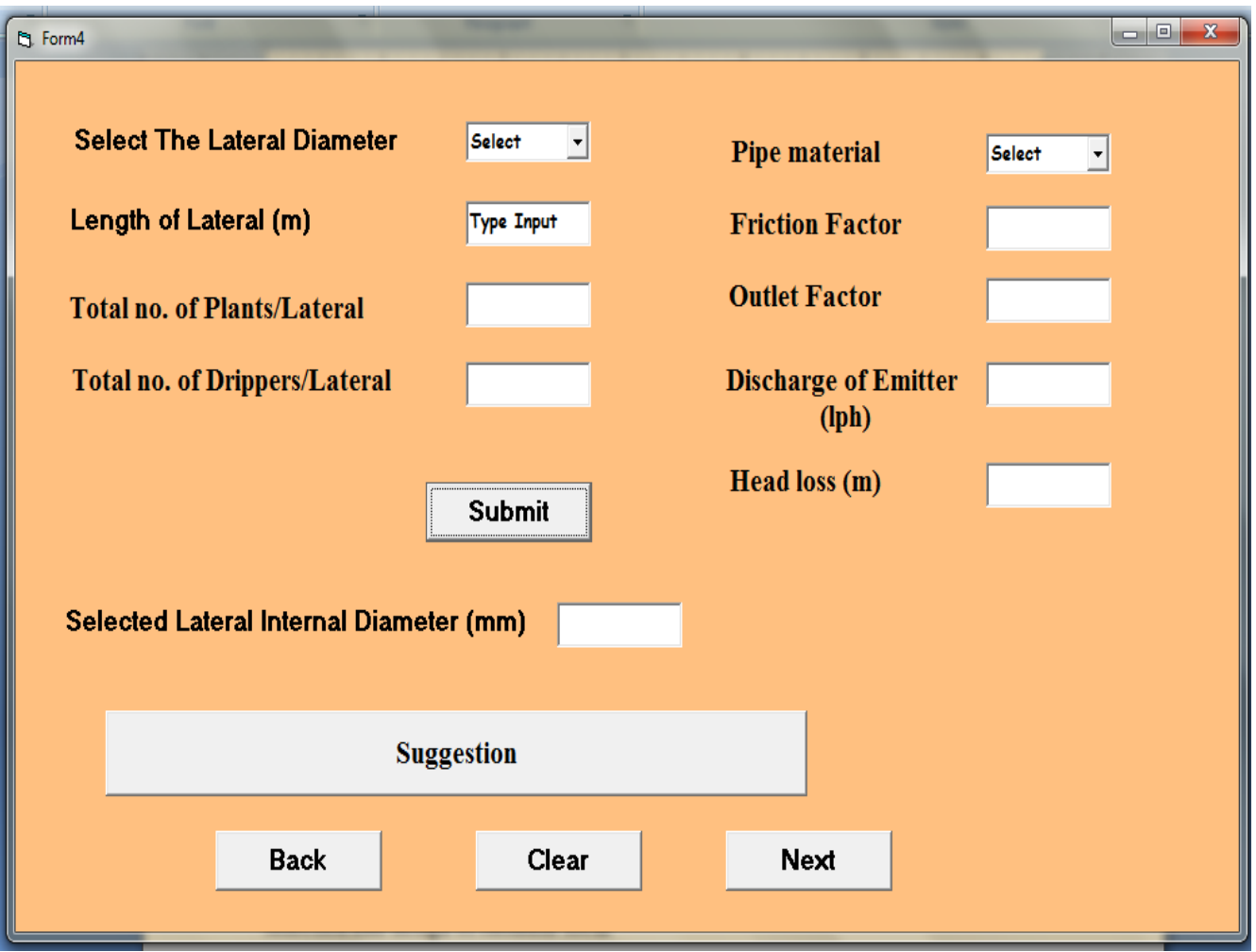

Fig.4 Design of submain form

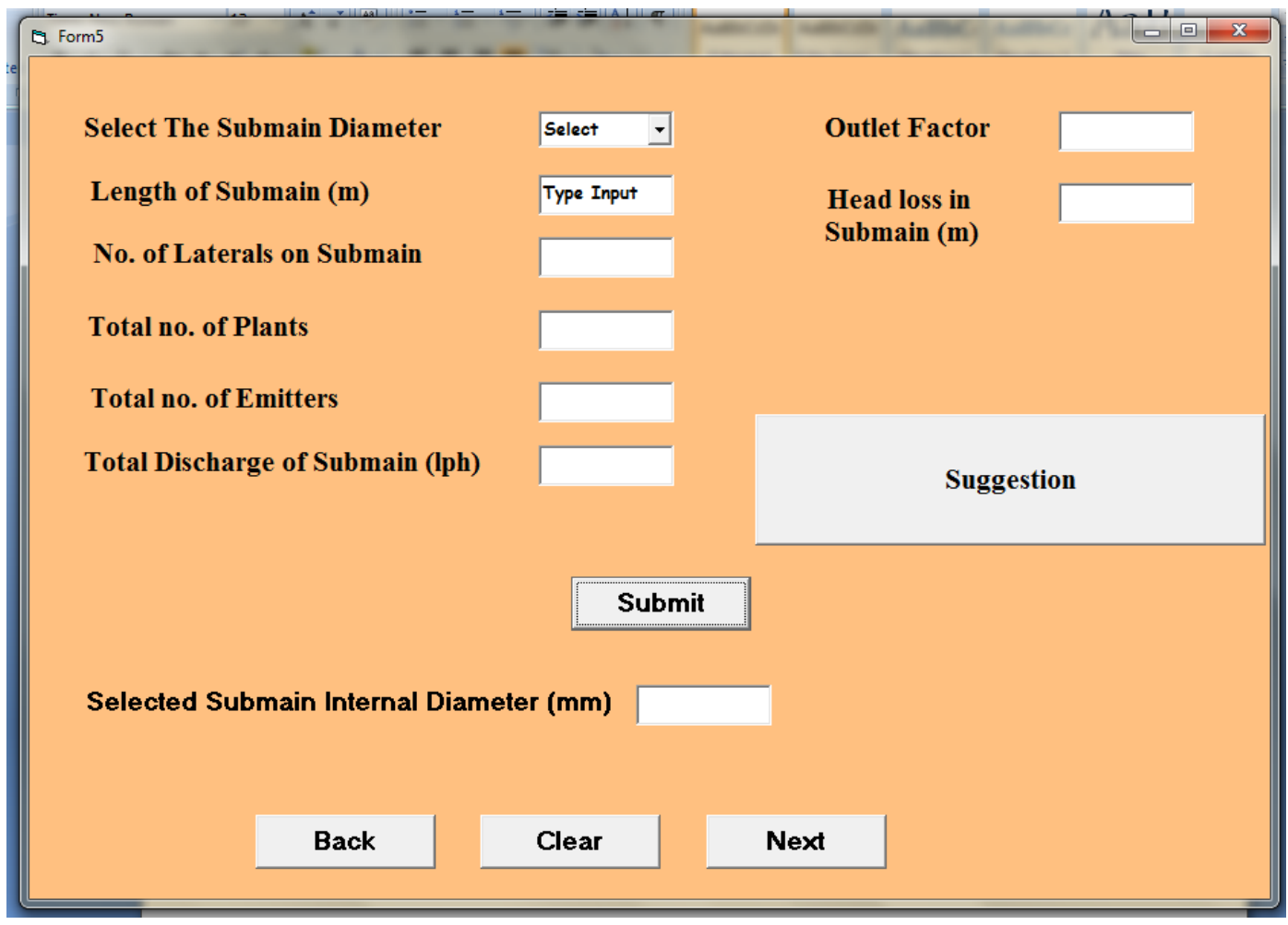


Fig.5 Design of mainline form

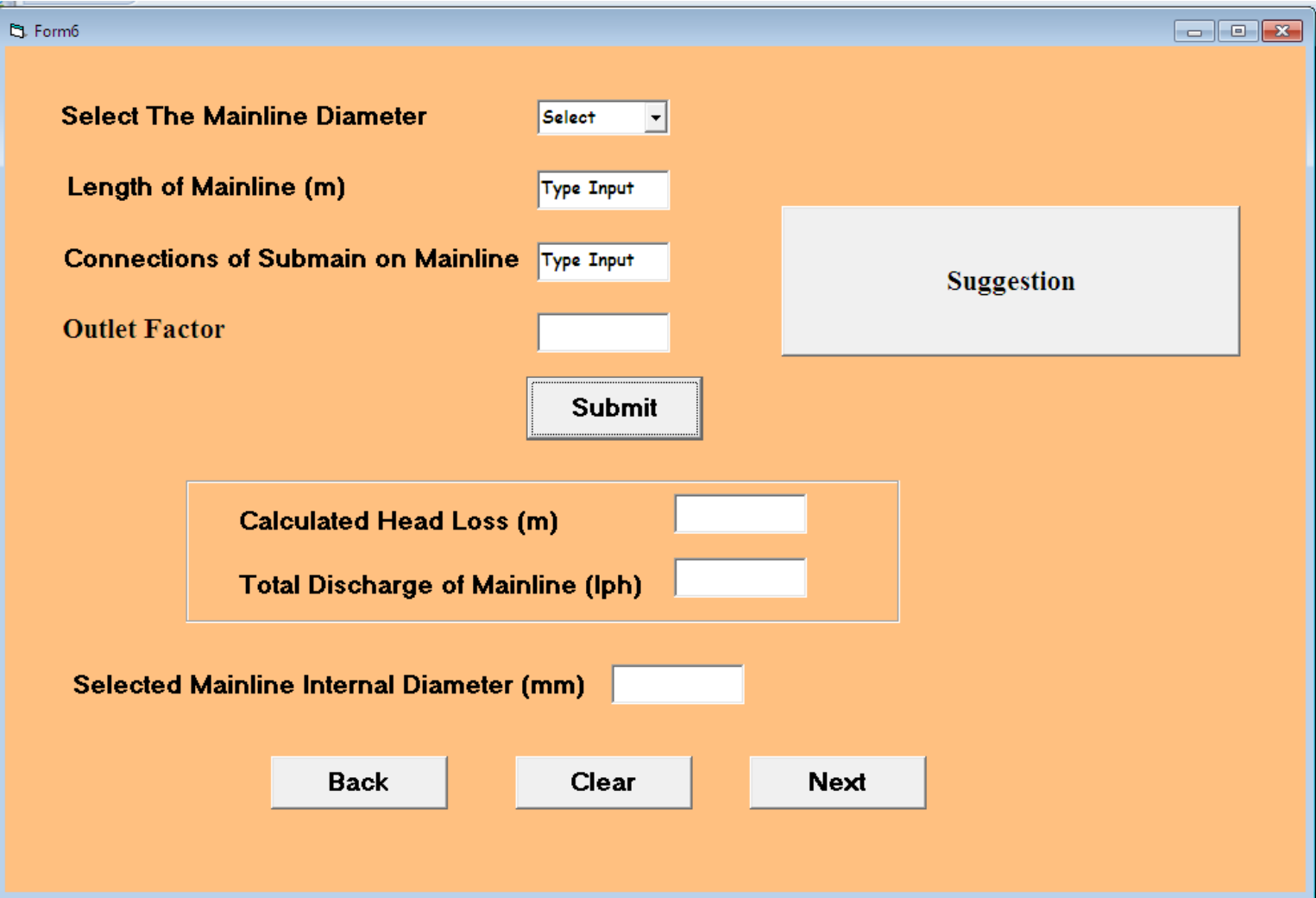

Fig.6 Design of pump form

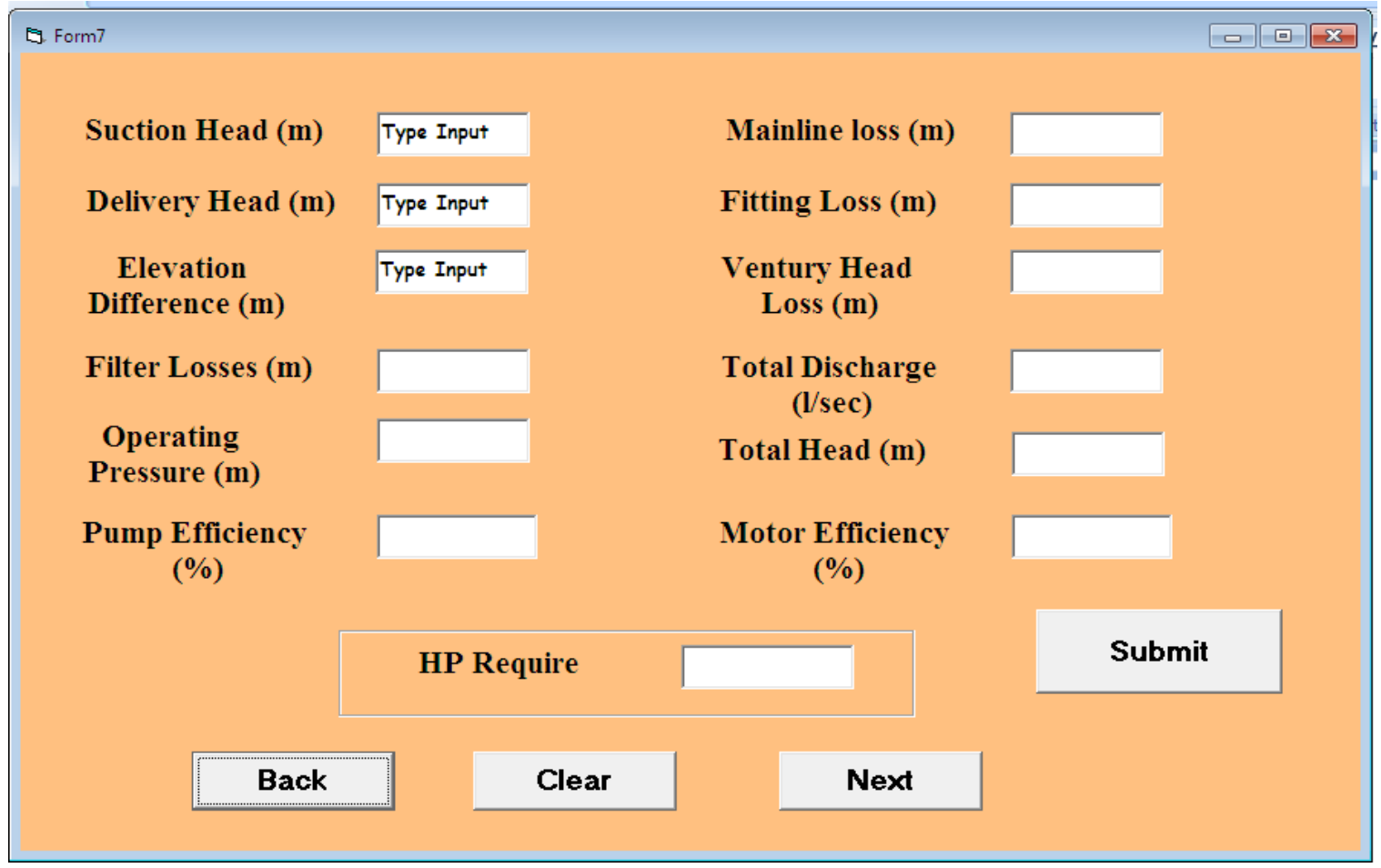


Fig.7 Detailed dimensions of designed drip irrigation system form

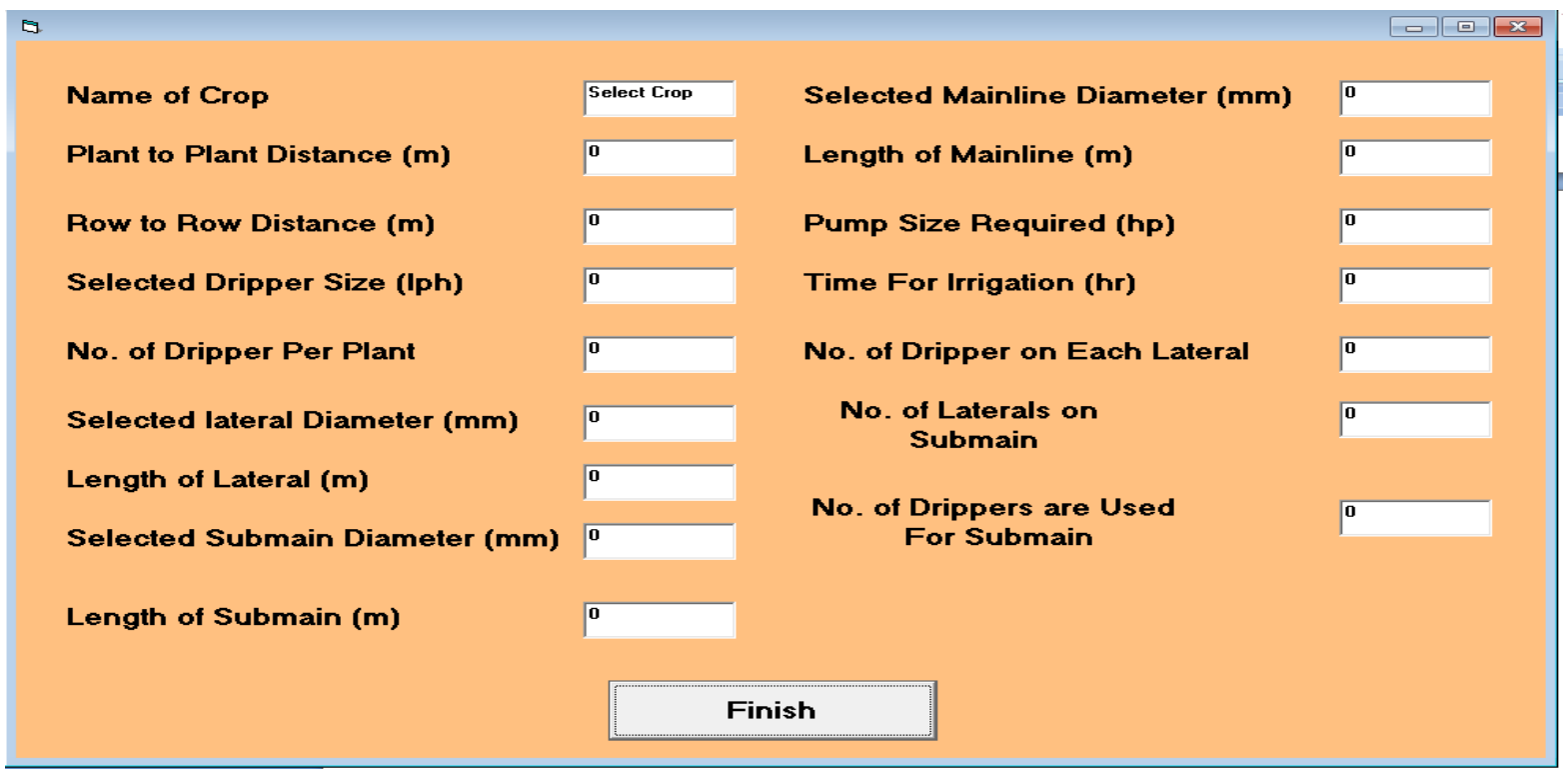

Table.1 Average values of crop factor for different crops

\begin{tabular}{|l|l|}
\hline Name of Crop & Crop factor $\left.\mathbf{~ K}_{\mathbf{C}}\right)$ \\
\hline Wheat & 0.675 \\
\hline Bean & 0.7625 \\
\hline Cabbage & 0.7875 \\
\hline Carrot & 0.7875 \\
\hline Cotton & 0.775 \\
\hline Cucumber & 0.7 \\
\hline Squash & 0.7 \\
\hline Tomato & 0.7875 \\
\hline Pulses & 0.7 \\
\hline Lentil & 0.7 \\
\hline Spinach & 0.7375 \\
\hline Maize & 0.8375 \\
\hline Millet & 0.7 \\
\hline Onion & 0.8 \\
\hline Peanut & 0.7375 \\
\hline Groundnut & 0.7375 \\
\hline Pepper & 0.75 \\
\hline Potato & 0.8 \\
\hline Radish & 0.7125 \\
\hline Sorghum & 0.7125 \\
\hline Soya bean & 0.7 \\
\hline Sugar beet & 0.8 \\
\hline Sunflower & 0.7 \\
\hline Tobacco & 0.775 \\
\hline
\end{tabular}


Table.2 Friction factor for different materials

\begin{tabular}{|l|l|}
\hline Material & Friction factor \\
\hline Aluminum & 130 \\
\hline Brass & 135 \\
\hline Cast iron & 130 \\
\hline Concrete & 120 \\
\hline Galvanized iron & 120 \\
\hline PVC & 150 \\
\hline Smooth Pipes & 140 \\
\hline Steel & 145 \\
\hline Wrought iron & 100 \\
\hline
\end{tabular}

\section{Selection and design of submain}

1. Select the submain diameter from the available list viz. $32 \mathrm{~mm}, 40 \mathrm{~mm}, 50 \mathrm{~mm}$, $63 \mathrm{~mm}$, and $75 \mathrm{~mm}$.

2. Enter the length submain to be required in meter.

3. Enter whether the lateral is connected either on one side of submain or on two side of submain.

4. Click on Submit button, if lateral friction head loss is less than 2 meter then message box will show "Your selected submain size is good, the calculated head loss is sufficient to carry the flow, go to next." Otherwise message box will display" your selected submain size is wrong, the calculated head loss is not sufficient to carry the flow, change the diameter".

5. Text box below shows the selected internal diameter of the submain.

6. Click on Next button to get next form.

7. To previous form click on Back button.

\section{Selection and design of main line}

1. Select the mainline diameter from the available list viz. $40 \mathrm{~mm}, 50 \mathrm{~mm}, 63 \mathrm{~mm}$, $75 \mathrm{~mm}, 90 \mathrm{~mm}$ and $110 \mathrm{~mm}$.

2. Enter the length mainline to be required in meter.
3. Enter the number of connections of submain on mainline,

4. Click on Submit button, if lateral friction head loss is less than 4 meter then message box will show your selected mainline size is good, the calculated head loss is sufficient to carry the flow, go to next. "Otherwise message box will display your selected mainline size is wrong, the calculated head loss is not sufficient to carry the flow, change the diameter".

5. Text box below shows the calculated head loss in meter and selected internal diameter of the mainline.

6. Click on Next button to get next form.

7. To go to previous form click on Back button.

\section{Selection of pump}

1. Select the use of filter assembly or and use of their ventury assembly.

2. Click on the button "HP required", which will show the motor size to be required for the system.

3. To go to previous form click on Back button.

4. Click on Next button to get all details of dimensions of designed drip irrigation system.

5. The software was developed to design of drip irrigation system, with taking onto 
calculation of crop water requirement, friction head loss of main line and operating pressure of system, which are very important for drip irrigation system design.

6. Facility to crop canopy and crop factor was provided with software Thus it can be used for calculating crop water requirement of any crop.

7. Design of system obtained by software was tested with on paper calculation at developer's level and results were found satisfactory.

8. Minimum input are provided to software and tested to size of laterals, sub mains and main lines with their lengths and friction head loss.

\section{References}

Asif, M., Ahmad, M., Mangrio, A.G., Akbar, $\mathrm{G}$ and Memon, A.H. 2015. Design, Evaluation and Irrigation Scheduling of
Drip Irrigation System on Citrus

Orchard. Pakistan Journal of Meteorology. 2(23): 37-48.

Boman, B and Shukla, S. 2004. Hydraulic considerations for citrus microirrigation systems. http://edis.ifas.ufl.edu.

FAO. 1999. Irrigation in Asia in figures. FAO Water Report No. 18. Rome.

Mane, M.S., Ayare, B.L and Magar, S.S. 2014. Principles of drip irrigation system. 1-76.

Michael, A.M and Ojha, T.P. 2006. Principles of agricultural engineering, volume II. 449-452.

Oladipo. I.O and Adewumi, J.K. 2013. Computer aided drip irrigation design for Nigerian Agricultural Environment. Open Access Scientific Reports. 2(2).

Sankara Reddi, G.H and Yellamanda Reddy, T. 2011. Efficient use of irrigation water. 175-185.

\section{How to cite this article:}

Gowtham Deekshithulu, N.V., G. Ravi Babu, H.V. Hema Kumar and Ganesh Babu, R. 2017. Design of Computer Aided Drip Irrigation System Software. Int.J.Curr.Microbiol.App.Sci. 6(12): 108-118. doi: https://doi.org/10.20546/ijcmas.2017.612.015 